\title{
Impact of reclaimed water irrigation on soil health in urban green areas
}

\author{
Weiping Chen ${ }^{\mathrm{a}, *}$, Sidan $\mathrm{Lu}^{\mathrm{a}}$, Neng Pan ${ }^{\mathrm{a}}$, Yanchun Wang ${ }^{\mathrm{b}}$, Laosheng $\mathrm{Wu}^{\mathrm{c}}$ \\ a State Key Laboratory of Urban and Regional Ecology, Research Center for Eco-Environmental Sciences, Chinese Academy of Sciences, Beijing 100085, China \\ ${ }^{\mathrm{b}}$ Beijing Garden Scientific Research Institute, Beijing 100102, China \\ ${ }^{\mathrm{c}}$ Department of Environmental Sciences, University of California, Riverside, CA 92521, United States
}

\section{H I G H L I G H T S}

- Reclaimed water irrigation improved soil nutrient conditions.

- Salinity increasing but no salinization occurred under reclaimed water irrigation.

- Difference of soil heavy metals contents under reclaimed and tap water irrigation is insignificant.

- Reclaimed water irrigation improved significantly soil microorganism activities.

\section{A R T I C L E I N F O}

\section{Article history:}

Received 3 March 2014

Received in revised form 9 July 2014

Accepted 13 July 2014

Available online 24 August 2014

Handling Editor: Keith Maruya

\section{Keywords:}

Reclaimed water irrigation

Soil nutrients

Soil salinity

Soil heavy metal pollutions

Soil microbial activities

\begin{abstract}
A B S T R A C T
Rapid increase of reclaimed water irrigation in urban green areas requires investigating its impact on soil health conditions. In this research, field study was conducted in 7 parks in Beijing with different histories of reclaimed water irrigation. Twenty soil attributes were analyzed to evaluate the effects of reclaimed water irrigation on the soil health conditions. Results showed that soil nutrient conditions were ameliorated by reclaimed water irrigation, as indicated by the increase of soil organic matter content (SOM), total nitrogen (TN), and available phosphorus (AP). No soil salinization but a slight soil alkalization was observed under reclaimed water irrigation. Accumulation of heavy metals in soil was insignificant. It was also observed that reclaimed water irrigation could significantly improve the soil microorganism activities. Overall, the soil health conditions were improved with reclaimed water irrigation, and the improvement increased when the reclaimed water irrigation period became longer.
\end{abstract}

(c) 2014 Elsevier Ltd. All rights reserved.

\section{Introduction}

In urban areas, demand for water has been increasing steadily, owing to population growth, industrial development, and needs for environmental enhancement. Irrigation with reclaimed water has become one of the important alternatives to sustain the existing water resources and enhance current urban water supplies in many cities (Biggs and Jiang, 2009). The conservational benefits of reclaimed water reuse in landscape irrigation are obvious (Anderson, 2003). Furthermore, it can reduce nutrient discharges into downstream and benefit the soil and plants as reclaimed water often contains high contents of $\mathrm{N}$ and $\mathrm{P}$, and many micronutrients (Duncan et al., 2009; Martinez et al., 2011).

The safety of reclaimed water irrigation was occasionally questioned as some potential hazardous compounds like salts and heavy metals were reported to accumulate in soils under reclaimed

\footnotetext{
* Corresponding author. Tel./fax: +86 1062843981.

E-mail address: wpchen@rcees.ac.cn (W. Chen).
}

water irrigation, thus reducing the soil functions (Toze, 2006). Field investigations had been conducted on heavy metal pollution (Smith et al., 1996; Kang et al., 2007; Xu et al., 2010; Yang et al., 2011), salinity (Stevens et al., 2003; Qian and Mecham, 2005; Wang et al., 2007; de Miguel et al., 2013), and microbial activities (Chen et al., 2008; Truu et al., 2009; Jiao et al., 2010; Adrover et al., 2012) in soils receiving reclaimed water from various sources and with different lengths of irrigation. But there was no conclusive report since the impact of reclaimed water irrigation on soil depends largely on the quality of reclaimed water, which varies with influent water characteristics and treatment process, irrigation practices, soil properties, plant characteristics and local climate conditions. So far, there were few comprehensive investigations including all these attributes to illustrate the impact of reclaimed water irrigation on soil health.

As the capital of China, Beijing has taken great efforts in municipal wastewater reclamation and reuse to satisfy the ever increasing demand for water. The city has become the national leader of reclaimed water reuse in recent years. In 2010, 680 million tons 
of reclaimed water from the municipal wastewater reclamation and recycling system was reused in Beijing, accounting for $19.3 \%$ of its total annual water consumption (Chang and Ma, 2012). The annual reuse amount is expected to be over 1000 million tons in 2015.

There were more than 60000 hectares urban green areas in Beijing, which consume about 220 million tons of water annually (Wang et al., 2011). To promote the reclaimed water irrigation, the government required all the parks to use reclaimed water for irrigation whenever it is possible. With the growth in reclaimed water reuse, it is imperative to understand the responses of urban landscape plants and soils to reclaimed water irrigation to assure the long-term success of this practice. The information will be useful to landscape planners and managers to determine what should be monitored and what proactive steps should be taken to minimize any negative effects of reclaimed water use.

The objective of this research was to comprehensively evaluate the effect of reclaimed water irrigation on urban green areas soil health conditions including nutrient conditions, salinity, heavy metal pollution, and microbial activities. Totally, 20 soil attributes were selected and measured. Seven parks with different lengths of reclaimed water irrigation in Beijing were selected for the investigation.

\section{Materials and methods}

\subsection{Soil sampling}

Field investigations were conducted in late May, 2011, in Beijing Plots in 7 parks located inside the 5th Ring Road of Beijing were selected for soil sampling. The region has a typical monsoon-influenced semi-humid continental climate with annual mean precipitation of about $520 \mathrm{~mm}$, annual mean temperature of $13.1^{\circ} \mathrm{C}$, and annual mean evaporation of about $980 \mathrm{~mm}$. The rainfall is unevenly distributed during the year, with more than $70 \%$ of the rainfall concentrated in July, August and September. Table 1 summarized some of the basic soil properties for these sites. The sites have Fluvo-aquic soil with soil pH ranging from 8.2 to 8.8 , sand content ranging from $65.0 \%$ to $79.1 \%$, silt content ranging from $15.9 \%$ to $28.5 \%$, and clay content ranging from $4.8 \%$ to $6.5 \%$.

Information for the sampling sites is also described in Table 1. The sampling plots had irrigated with reclaimed water for 39 years. The amount of reclaimed water irrigation was about $400 \mathrm{~mm}$ per year using typical local management practices (if no precipitation, the plots were irrigated $2-3$ times per week during the growth season with drip irrigation or sprinkler irrigation).
Four plots irrigated with reclaimed water were randomly selected at each park. At each plot, paired soil samples were taken at depths of $0-10 \mathrm{~cm}$, and $10-20 \mathrm{~cm}$ using a $5 \mathrm{~cm}$ bucket auger. Each of the paired soil samples was a composite of five to seven sub-samples that were taken randomly from the entire grassland plot (greater than $300 \mathrm{~m}^{2}$ ). Approximately $1 \mathrm{~kg}$ of composite soil was collected from each plot. Eleven control plots were selected in 3 of the 7 parks. Soil sampling for the control plots followed the same method as described above. The control plots were irrigated with tap water following similar irrigation practices as those using reclaimed water. Table 2 shows some basic properties of reclaimed water (RW) and tap water (TW) used in the parks.

The soil samples were air dried, ground and screened to pass a sieve with 10 mesh openings or 100 mesh openings (for analysis of different attributes), and stored in the plastic bags for further analysis.

\subsection{Soil samples analysis}

Based on results from existing literatures, a total of 20 attributes reflecting the soil health conditions were measured, including (1) soil nutrient condition attributes of soil $\mathrm{pH}(\mathrm{pH})$, soil organic matter content (SOM), total nitrogen (TN), available phosphorus (AP); (2) soil salinity related attributes of electrical conductivity of the saturated soil-paste $\left(\mathrm{EC}_{\mathrm{e}}\right)$, sodium adsorption ratio (SAR), and total porosity (TP) and total boron (TB); (3) soil heavy metal contents of $\mathrm{As}, \mathrm{Cd}, \mathrm{Cr}, \mathrm{Cu}, \mathrm{Pb}, \mathrm{Zn}$; and (4) soil microbial attributes of soil microbial biomass carbon (MBC), enzyme activity of urease, alkaline phosphatase, invertase, dehydrogenase, and catalase.

Soil $\mathrm{pH}$ was determined in distilled water at a soil-to-solution mass ratio of $1: 5$ by a Mettler-Toledo $320-\mathrm{S}$ pH meter. Soil organic matter, total nitrogen and available phosphorus were determined based on Bao (2000) by external heating method for the determination of potassium dichromate, potassium dichromate-sulfuric acid digestion and Olsen method, respectively.

Electrical conductivity of the soil extracts at soil and water ratio of 1:5 (EC $\left.C_{1: 5}\right)$ was measured by a Mettler Toledo 326 conductivity meter. $\mathrm{EC}_{1: 5}$ was then transformed to $\mathrm{EC}_{\mathrm{e}}$ based on the results of $\mathrm{Li}$ et al. (1996). SAR was obtained based on the concentrations of $\mathrm{Na}^{+}$, $\mathrm{Ca}^{2+}$ and $\mathrm{Mg}^{2+}$ determined by ICP-OES. Total porosity was determined by ring sampler method.

Aliquots of $0.25 \mathrm{~g}$ finely ground soil were digested using a 4acid mixture containing $10 \mathrm{ml} \mathrm{HCl}, 5 \mathrm{ml} \mathrm{HNO}, 5 \mathrm{ml} \mathrm{HF}$, and $3 \mathrm{ml}$ $\mathrm{HClO}_{4}$. Digested extracts were combined with $1: 1$ aqua regia and made up to $50 \mathrm{ml}$ with deionized water for the soil $\mathrm{Cu}, \mathrm{Zn}, \mathrm{Cr}$ con-

Table 1

Number of plots, irrigation histories, and irrigation water sources for the treated and control plots, and some basic soil properties in the 7 sampling parks. ${ }^{\mathrm{a}}$

\begin{tabular}{|c|c|c|c|c|c|c|c|c|}
\hline Site & & TRT & LT & ВТВ & LY & RCEES & $\mathrm{CY}$ & OFP \\
\hline \multirow[t]{3}{*}{ Treated plots } & Number & 4 & 4 & 4 & 4 & 4 & 4 & 4 \\
\hline & Irrigation history & 9 years & 9 years & 9 years & 9 years & 6 years & 4 years & 3 years \\
\hline & Irrigation water source & $\mathrm{RW} \# 1^{\mathrm{b}}$ & RW\#1 & RW\#1 & Self-produced & RW\#3 ${ }^{\mathrm{d}}$ & $\mathrm{RW} \# 2^{\mathrm{c}}$ & RW\#2 \\
\hline \multirow[t]{2}{*}{ Control plots } & Number & 4 & - & 3 & - & 4 & - & - \\
\hline & Irrigation water source & TW & - & TW & - & TW & - & - \\
\hline \multirow[t]{6}{*}{ Soil properties } & Bulk density $\left(\mathrm{g} \mathrm{cm}^{-3}\right)$ & 1.45 & 1.51 & 1.44 & 1.46 & 1.39 & 1.36 & 1.65 \\
\hline & $\mathrm{pH}(-)$ & 8.38 & 8.44 & 8.20 & 8.63 & 8.61 & 8.60 & 8.71 \\
\hline & Clay (\%) & 4.86 & 6.30 & 4.78 & 5.08 & 6.49 & 6.55 & 5.90 \\
\hline & Silt (\%) & 15.94 & 21.13 & 16.14 & 19.27 & 22.84 & 28.45 & 23.56 \\
\hline & Sand $(\%)$ & 79.19 & 72.58 & 79.08 & 75.64 & 70.67 & 65.00 & 70.53 \\
\hline & $\mathrm{CEC}\left(\mathrm{cmol} \mathrm{kg}^{-1}\right)$ & 21.4 & 13.9 & 11.1 & 19.3 & 17.0 & 13.3 & 32.4 \\
\hline
\end{tabular}

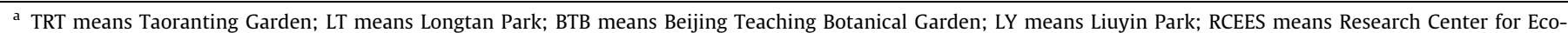
environmental Sciences; CY means Chaoyang Park; OFP means Olympic Forest Park. RW represents reclaimed water; TW represents tap water.

b From Beijing sixth water source plant, under treatment process of anaerobic-anoxic-oxic denitrification biofilter, film filter and ozone oxidation.

c From Beixiaohe effluent treatment plant, under treatment process of membrane bio-reactor + reverse osmosis.

d Self-produced from Research Center for Eco-environmental Sciences, under treatment process of activated carbon filter and ozone oxidation. 
Table 2

Basic properties of reclaimed water and tap water used in the study parks. ${ }^{a}$

\begin{tabular}{|c|c|c|c|c|c|c|c|c|}
\hline & $\mathrm{pH}\left(25^{\circ} \mathrm{C}\right)$ & TDS $\left(\mathrm{mg} \mathrm{L}^{-1}\right)$ & $\mathrm{COD}_{\mathrm{Mn}}\left(\mathrm{mg} \mathrm{L}^{-1}\right)$ & $\mathrm{NH}_{3}-\mathrm{N}\left(\mathrm{mg} \mathrm{L}^{-1}\right)$ & $\mathrm{TN}\left(\mathrm{mg} \mathrm{L}^{-1}\right)$ & $\mathrm{TP}\left(\mathrm{mg} \mathrm{L}^{-1}\right)$ & $\operatorname{SAR}\left(\mathrm{mg} \mathrm{L}^{-1}\right)$ & $\mathrm{Cl}^{-}\left(\mathrm{mg} \mathrm{L}^{-1}\right)$ \\
\hline RW\#1 & 7.43 & 752.3 & 40.3 & 1.44 & 24.6 & 0.38 & 2.59 & 174.5 \\
\hline RW\#2 & 7.32 & 537.6 & 50.1 & 1.45 & 25.8 & 0.53 & 2.32 & 93.8 \\
\hline RW\#3 & 7.50 & 418 & 45.2 & 5.75 & 16.3 & 1.26 & 0.73 & 56.0 \\
\hline TW & 7.8 & 310 & - & 0.20 & 1.70 & 0.02 & 10.0 & 27.1 \\
\hline
\end{tabular}

a RW\#1, RW\#2 and RW\#3 represent respectively reclaimed water from Beijing sixth water source plant, from Beixiaohe effluent treatment plant and self-produced by

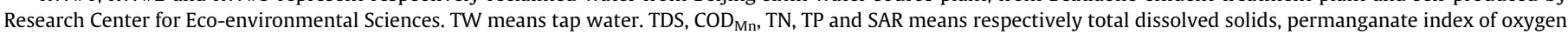
demand, total nitrogen, total phosphorus, and sodium adsorption ratio.

centration analysis using ICP-OES, for the soil As concentration analysis using atomic fluorescence spectrometer, and it was further diluted to $250 \mathrm{ml}$ for analyses of $\mathrm{Cd}$ and $\mathrm{Pb}$ using ICP-MS.

The activities of five selected soil enzymes were assayed following the method described by Frankenberger and Johanson (1983) for invertase, by Gosewinkel and Broadbent (1984) for urease, by Kramer and Yerdei (1960) for alkaline phosphatase, by Johnson and Temple (1964) for catalase, by Stevenson (1959) for dehydrogenase. Soil microbial biomass carbon was determined by the chloroform fumigation-extraction method (Vance et al., 1987) using Liqui TOC II.

\subsection{Statistical analysis}

To study the impacts of reclaimed water irrigation on soil health, the mean values of 20 soil attributes under reclaimed water irrigation (treated plots, 28 replicates) were compared with those under tap water irrigation (control plots, 11 replicates) using the one-way ANOVA and post hoc Tukey's multiple comparison tests at the 0.05 significance level. Because sampling sites had different years of irrigation with the similar soil properties, climate conditions, plant cover, and even the management practices, mean values of 20 parameters under the cases of 3 years ( 8 replicates), 6 years ( 4 replicates) and 9 years ( 16 replicates) were compared following the same method to study the impacts of irrigation history. All statistical analyses were conducted using the software SPSS 13.0 (SPSS Inc., Chicago, IL, USA).

\section{Results and discussion}

\subsection{Impacts on the soil nutrient conditions}

Unless special treatment processes are employed, reclaimed water often contains high content of $\mathrm{N}$. As shown in Table 2, the $\mathrm{N}$ content in the reclaimed water of Beijing was over $20 \mathrm{mg} \mathrm{L}^{-1}$. It can add great amount of $\mathrm{N}$ to soil system. In addition, reclaimed water irrigation can provide the soils with phosphorous, organic matter and other nutrients. Fig. 1 illustrates the differences of the four parameters related with soil nutrient conditions between soils receiving tap water and reclaimed water irrigation.

Impacts of reclaimed water irrigation on soil $\mathrm{pH}$ were quite limited (Fig. 1A), mainly because that $\mathrm{pH}$ values of the soils in Beijing area are relatively high. The soil $\mathrm{pH}$ values at both soil layers were around 8.0, with a very small variation among sites. On average, the differences between plots irrigated with tap water and reclaimed water were less than 0.04 units. While some researchers reported that reclaimed water irrigation could result in a slight increase of soil pH due to its high content of $\mathrm{HCO}_{3}^{-}$, salinity and nutrients (Stewart et al., 1990; Mancino and Pepper, 1992; Qian and Mecham, 2005), no significant change of soil pH was yet noticed in this research.

Reclaimed water irrigation resulted in a slight increase of soil $\mathrm{TN}$ and AP in both soil layers (Fig. 1B and C). In comparison with tap water irrigation, reclaimed water irrigation leaded to an average of $17 \%$ and $10 \%$, respectively, increase in $\mathrm{TN}$ in the 0 $10 \mathrm{~cm}$ and $10-20 \mathrm{~cm}$ soil layer. Similarly for AP, the average increase was $14 \%$ and $6 \%$, respectively, in the $0-10 \mathrm{~cm}$ and $10-$ $20 \mathrm{~cm}$ soil layer. The increase was however insignificant based on the Tukey's test. The increase of TN and TP in soil was small under reclaimed water irrigation, which may be attributed to that most of the $\mathrm{N}$ and $\mathrm{P}$ in reclaimed water are in forms that can be easily used by plants (Duncan et al., 2009).

A slight increase trend of SOM in the $0-10 \mathrm{~cm}$ and $10-20 \mathrm{~cm}$ soil layers was found under reclaimed water irrigation, compared with that of the tap water irrigation (Fig. 1D). The SOM under TW and RW irrigation in the $0-10 \mathrm{~cm}$ soil layer was significantly higher than that in the $10-20 \mathrm{~cm}$ soil layer. Overall, the difference in SOM change between the TW and RW irrigation in the top $20 \mathrm{~cm}$ was quite small. While the reclaimed water contains certain amount of organic matter (with a COD of about $40 \mathrm{mg} \mathrm{L}^{-1}$, Table 2), the addition of organic matter with reclaimed water is relatively small comparing with the soil pool. Thus, no increase of SOM in top layer soils was noticed.

In general, the soil nutrient conditions were ameliorated to some extent by reclaimed water irrigation. The improvement of soil nutrient conditions was however insignificant, as most of these nutrients provided by reclaimed water can be used by plants or degraded in soil.

\subsection{Impacts on the soil salinity}

The salinity level in reclaimed water is invariably higher than in its corresponding source water. As showed in Table 2, the total dissolved solids (TDS) of the reclaimed water in Beijing was about $800 \mathrm{mg} \mathrm{L}^{-1}$, which was about 2-fold of the tap water. Thus, reclaimed water irrigation may conceivably lead to increase of soil salinity level. Fig. 2 illustrates the changes of the four parameter related to salinity of the soils receiving tap water and reclaimed water irrigation.

Comparing with those irrigated with tap water, the average $\mathrm{EC}_{\mathrm{e}}$ in plots irrigated with reclaimed water was increased by $21 \%$ and $17 \%$, respectively, in the $0-10 \mathrm{~cm}$ and $10-20 \mathrm{~cm}$ soil layers (Fig. 2A). Accumulation of salts in soils is affected by many factors including the quality of irrigation water, irrigation practices, soil properties and plant characteristics. In addition, it varies with irrigation cycles. Therefore, soil salinity in our study varied greatly from $0.90 \mathrm{dS} \mathrm{m}^{-1}$ to $7.33 \mathrm{dS} \mathrm{m}^{-1}$ from park to park due to the huge variation of salinity level in reclaimed water.

Overall, a slight difference between plots irrigated with TW and $\mathrm{RW}$ was found. The average $\mathrm{EC}_{\mathrm{e}}$ value was $1.81 \mathrm{dS} \mathrm{m}^{-1}$ in the $0-$ $10 \mathrm{~cm}$ soil layer and $1.59 \mathrm{dS} \mathrm{m}^{-1}$ in the $10-20 \mathrm{~cm}$ soil layer. According to United States Department of Agriculture Handbook 60 (US Salinity Laboratory Staff, 1954), there was no soil salinization under reclaimed water irrigation (based on mean value), which could be attribute to the over irrigation practices in the parks of Beijing. In many cases, soil salinization appeared under reclaimed water irrigation due to either low leaching fraction, or 

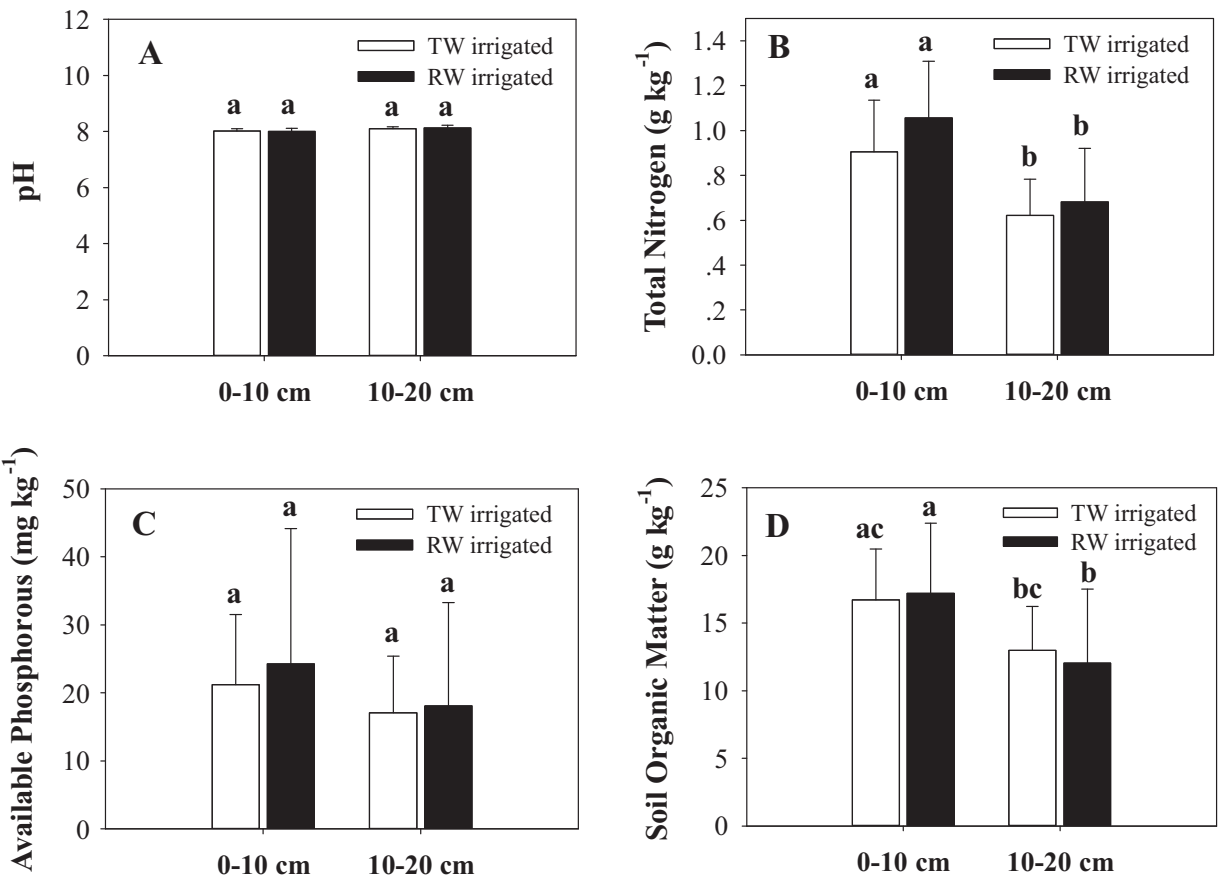

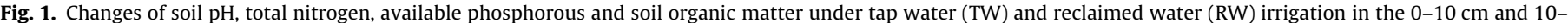
$20 \mathrm{~cm}$ soil layers. Columns marked with the same letter do not differ statistically from each other at $p<0.05$.
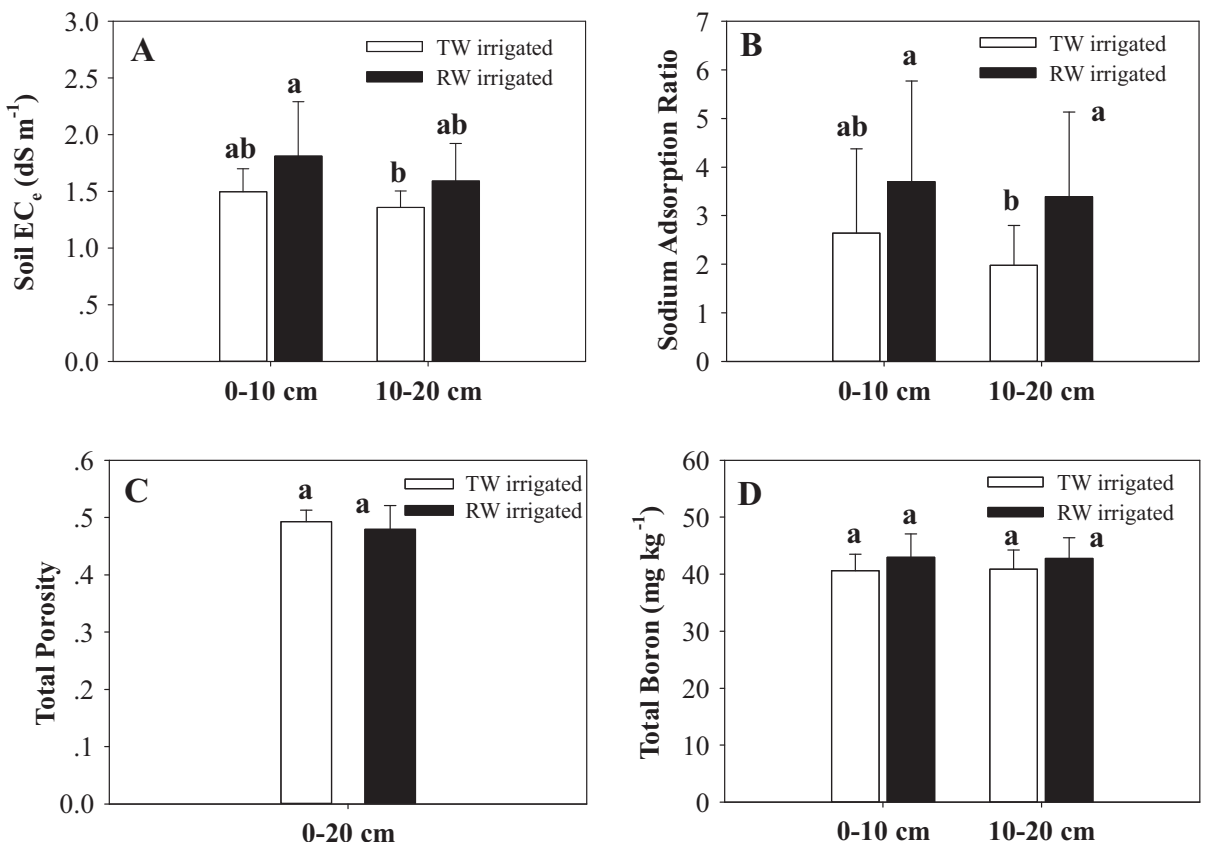

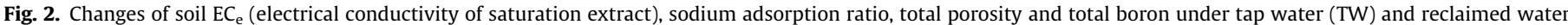
(RW) irrigation in the $0-10 \mathrm{~cm}$ and $10-20 \mathrm{~cm}$ soil layers. Columns marked with the same letter do not differ statistically from each other at $p<0.05$.

heavy soil texture (Candela et al., 2007; Palacios-Díaz et al., 2009; Chen et al., 2013).

Reclaimed water contains proportionally higher in $\mathrm{Na}^{+}$vs. $\mathrm{Ca}^{2+}$ and $\mathrm{Mg}^{2+}$, namely, it can increase the sodium adsorption ratio (SAR) in soil which can cause severe permeability problems. Field investigation results showed that there was a significant difference of SAR in both soil layers between those irrigated with tap water and reclaimed water (Fig. 2B). In the $0-10 \mathrm{~cm}$ soil layer, the average SAR in the plots irrigated with reclaimed water increased by
$40 \%$ (from 2.64 to 3.70 ). In the $10-20 \mathrm{~cm}$ soil layer, the average SAR in the plots irrigated with reclaimed water increased by $70 \%$ (from 1.98 to 3.39). For the total porosity, the change was quite limited and insignificant (Fig. 2C). No significant permeability issues would occur with reclaimed water irrigation, as the significant increasing of SAR did not lead the increasing of total porosity and change of soil structure.

Because of household detergents and cleansing agents in the wastewater, concentration of boron in reclaimed water is generally 
much higher than that in tap water. Accumulation of boron in soil is of concern because plant tolerance to boron in soil varies widely. Under reclaimed water irrigation, an increase trend of total boron content was observed but this trend was insignificant (Fig. 2D). The total boron content in these sites maintained a level of around $40 \mathrm{mg} \mathrm{kg}^{-1}$, which is close to the background range of the study region (Wei et al., 1991).

In summary, reclaimed water irrigation resulted in the increase of soil salinity and toxic salt ions (eg. $\mathrm{Na}^{+}$, boron). The difference between tap water and reclaimed water irrigation was however insignificant except for SAR. The salinity issues associated with reclaimed water irrigation have been broadly noticed (Stevens et al., 2003; Qian and Mecham, 2005; Wang et al., 2007; Chen et al., 2012; de Miguel et al., 2013), but the problems are not special and can be alleviated with proper irrigation management.

\subsection{Impacts on the soil heavy metal contents}

Because heavy metal pollution industry had been moved out of the city in recent years, and discharges of industrial wastewater were well regulated, heavy metals concentration in reclaimed water in Beijing is largely negligible. In addition, heavy metals can be effectively removed from wastewater treatment processes and be concentrated in the sludge fraction. Fig. 3 illustrated the changes of the contents of six heavy metals in soils irrigated with tap water and reclaimed water.

There was a slight increase of soil As, $\mathrm{Cd}$ and $\mathrm{Cr}$ contents in both layers under reclaimed water irrigation, but the difference between soils irrigated with reclaimed water and with tap water was less than $10 \%$ and was insignificant (Fig. 3A-C). For soil heavy metals $\mathrm{Cu}, \mathrm{Pb}$ and $\mathrm{Zn}$, there was even a slight decrease of their contents in both soil layers (Fig. 3D-F). The heavy metal input from reclaimed water is generally small in comparison with atmospheric deposition (Luo et al., 2009). Therefore, there was no significant difference on contents of six heavy metals in plots irrigated with reclaimed water and with tap water.

Heavy metals $\mathrm{As}, \mathrm{Cr}, \mathrm{Cd}$, and $\mathrm{Pb}$ which are not the essential elements for plant growth are harmful to plants, and excessive accumulation of $\mathrm{Cu}$ and $\mathrm{Zn}$ in soil would also be harmful for plants. Soil heavy metal contents in all plots did not exceed the national standards, and thus would not affect plant growth and human health. Overall, heavy metals do not constitute a problem at the present stage with the irrigation of reclaimed water in Beijing. In case that untreated sewage or effluents of primary treatments are used, or there are significant industrial sources of heavy metals in the municipal wastewater collection system, the heavy metal issues should be addressed. However, more researches are needed to clarify environmental risks of heavy metals under longer time reclaimed water irrigation as they may slowly accumulate in soil with time.
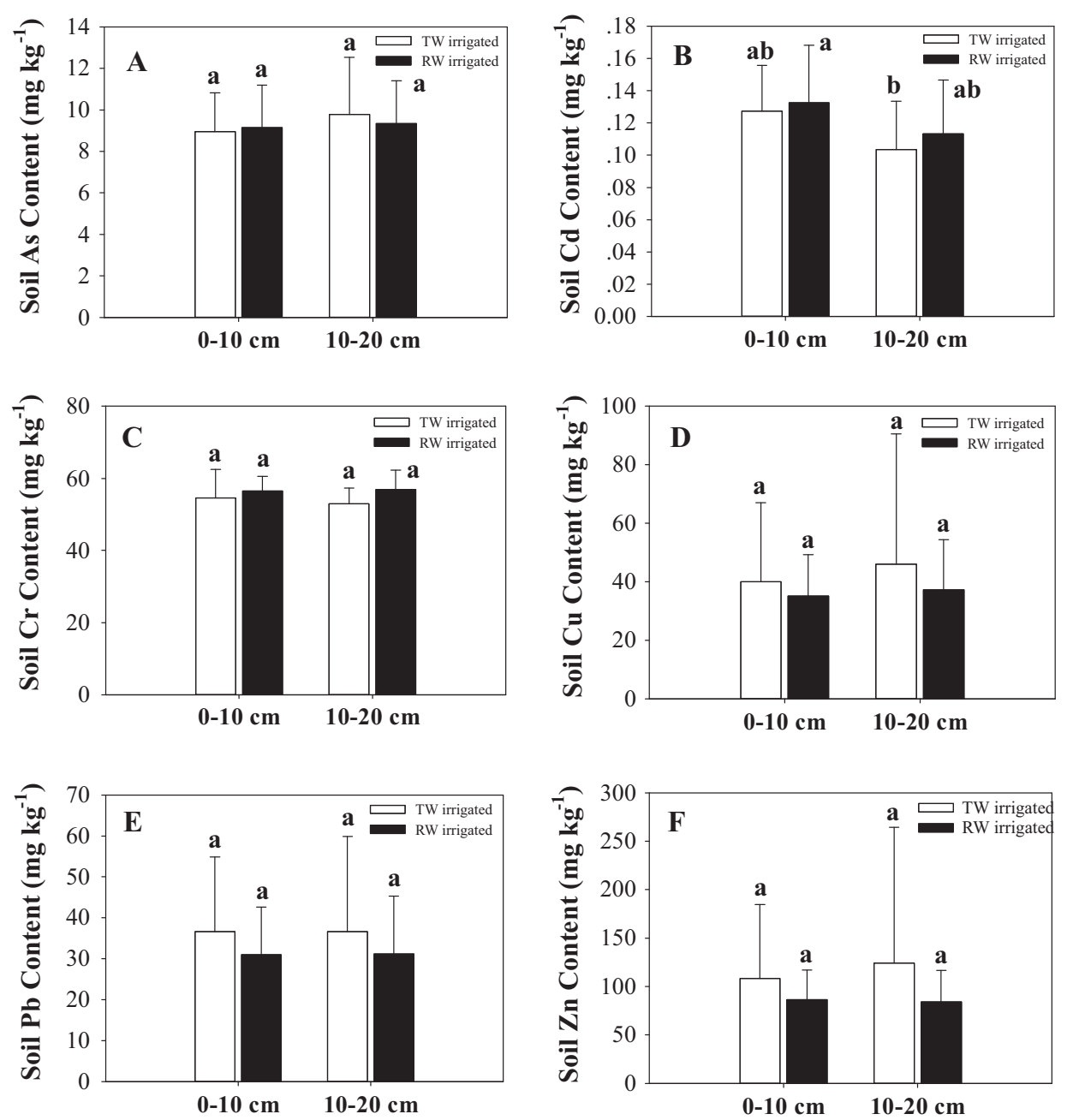

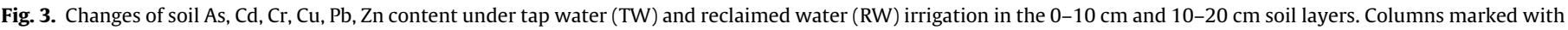
the same letter do not differ statistically from each other at $p<0.05$. 


\subsection{Impact on the soil biological activities}

Reclaimed water can provide soil with extra nutrients and beneficial microorganisms, but it can also introduce potentially harmful trace elements and organic constituents, such as heavy metals, pesticides and polycyclic aromatic hydrocarbons, to soils. Thus, the microbial dynamics may change gradually when soils are irrigated with reclaimed water (Chen et al., 2008). Fig. 4 illustrates the changes of MBC and activities of five soil enzymes under tap water and reclaimed water irrigation.

Measurement of the soil microbial biomass carbon has been widely adopted as a relatively simple means of assessing the impact of environmental and anthropogenic change on soil microorganisms (Insam and Domsch, 1988). In comparison with TW irrigation, there was an increase in the soil microbial biomass carbon in both soil layers under RW irrigation (Fig. 4A). Soil MBC in the 0 $10 \mathrm{~cm}$ soil layer was significantly higher than that in the $10-20 \mathrm{~cm}$ soil layer. In comparison with tap water irrigation, the average $M B C$ values in plots with reclaimed water irrigation showed an average increase of $58 \%$ and $62 \%$, respectively, in the $0-10 \mathrm{~cm}$ and $10-20 \mathrm{~cm}$ soil layers. The results suggested that reclaimed water irrigation could significantly improve the soil microorganism activities, and then the soil health conditions.

Invertase, urease and alkaline phosphatase are some of the major soil enzymes regulating the cycling of three main biologically important nutrients $\mathrm{C}, \mathrm{N}$ and $\mathrm{P}$, respectively. In comparison with tap water irrigation, their average activities in plots irrigated reclaimed water increased by $1.56,1.19$ and 1.35 fold, respectively, in the $0-10 \mathrm{~cm}$ soil layer, and by $2.09,1.25$ and 1.46 fold, respectively, in the $10-20 \mathrm{~cm}$ soil layer (Fig. 4D, B, and C). For invertase and alkaline phosphatase, there was significant difference in their activities between the plots irrigated with reclaimed water and those irrigated with tap water. However, the increase of soil urease activity was insignificant in urban green areas since urea was seldom applied.

Catalase and dehydrogenase are commonly used as an indicator of the biological status of soil (Nannipieri et al., 1990). Catalase is responsible for the breakdown of hydrogen peroxide yielding water and molecular oxygen, while dehydrogenase reflects the total range of oxidative activity of soil microflora. Compared with those irrigated with tap water, the average dehydrogenase activity in plots irrigated reclaimed water increased by $29 \%$ and $26 \%$, respectively, in the $0-10 \mathrm{~cm}$ and $10-20 \mathrm{~cm}$ soil layers (Fig. $4 \mathrm{E}$ ). For catalase, the increase was $7.7 \%$ and $13 \%$, respectively, in the $0-10 \mathrm{~cm}$ and $10-20 \mathrm{~cm}$ soil layers (Fig. 4F).

Overall, the biogeochemical processes governing C, N, P, and S cycling will go smoothly, and the integrity of the ecosystem functions will be not breached, because the soil enzyme activities are enhanced under reclaimed water irrigation. Similar results were found in five long-term reclaimed wastewater irrigation sites in southern California where the overall activities of 17 soil enzymes associated with the $\mathrm{C}, \mathrm{N}, \mathrm{P}$, and $\mathrm{S}$ cycles were enhanced by an
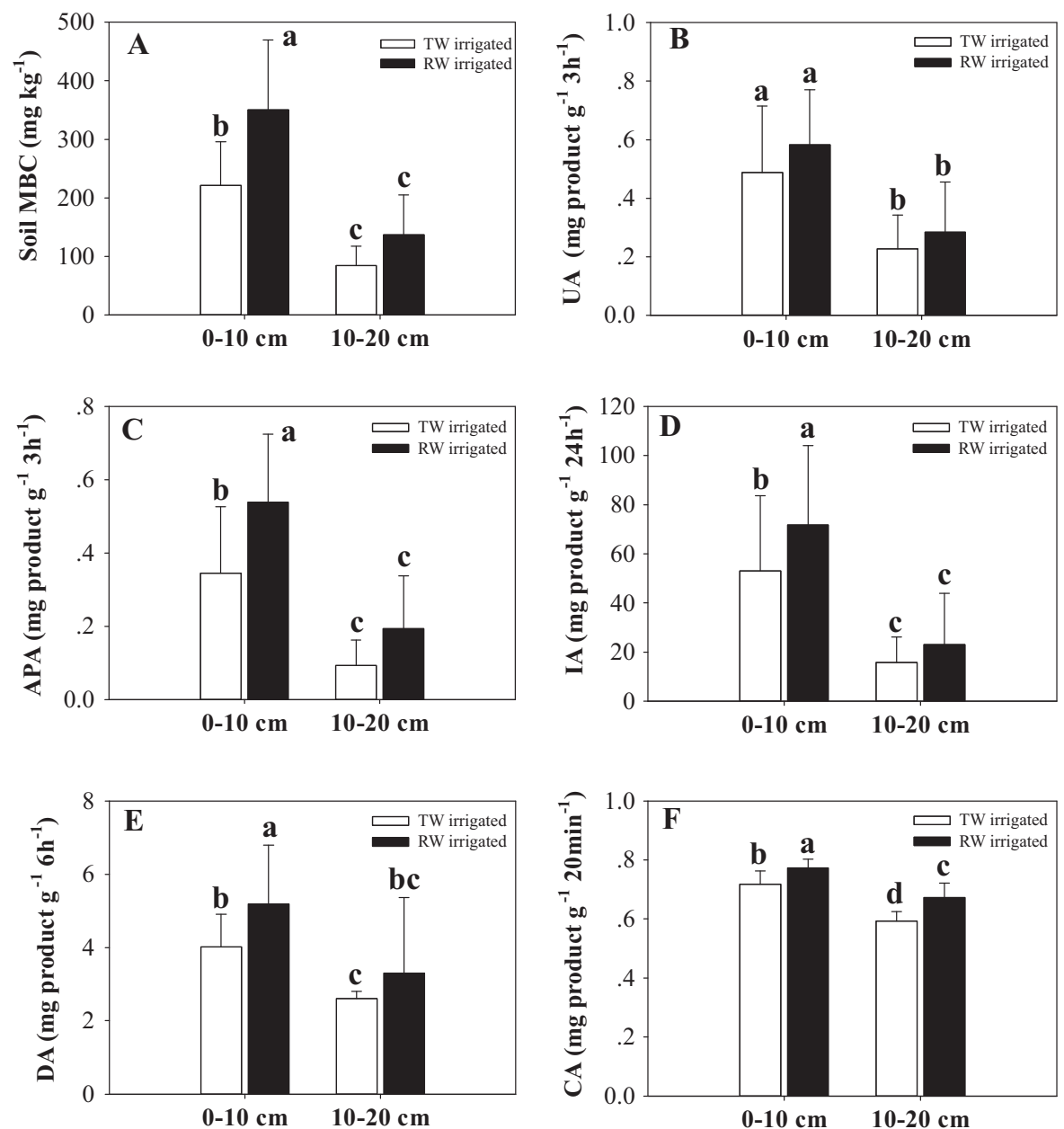

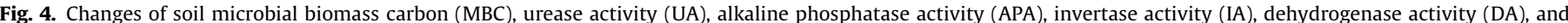

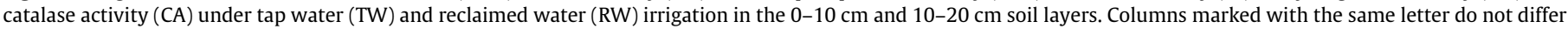
statistically from each other at $p<0.05$. 
average of 2.2-fold to 3.1-fold in comparison with their respective controls (Chen et al., 2008).

\subsection{Impact of reclaimed water irrigation history on soil attributes}

Table 3 illustrates the changes of parameters related soil health with irrigation years (some parameters were not showed as they did not change with the increase of irrigation years). The coefficient of variation (CV) of 20 parameters under the different irrigation years was small and no outlier was found. An increase trend of TN and SOM was observed in the $0-10 \mathrm{~cm}$ soil layer from 3 years to 9 years irrigation history. In comparison with 3 years irrigation history, soil TN and SOM with 9 years irrigation history increased significantly (33.3\% and $50.4 \%$, respectively, in the $0-10 \mathrm{~cm}$ and $10-20 \mathrm{~cm}$ layers). The results suggested that as irrigation years increase, soil nutrient condition was improved under reclaimed water irrigation. For the $10-20 \mathrm{~cm}$ soil layer, large differences of TN and SOM between plots with 3 years and 9 years irrigation history was also observed, but they were statically insignificant, indicating that it might be affected by other factors like soil properties and reclaimed water quality.

There were $11.8 \%$ and $43.3 \%$, respectively, increases of $\mathrm{EC}_{\mathrm{e}}$ and SAR in the $0-10 \mathrm{~cm}$ soil layer as RW irrigation years increased from 3 years to 9 years. Changes of $\mathrm{EC}_{\mathrm{e}}$ and SAR with irrigation years in the $10-20 \mathrm{~cm}$ soil layer were neglectable. Since accumulation of soil salinity was affected by many factors and may approach an equilibrium state in 3 years under over irrigation practice (Chen et al., 2013), impact of irrigation years on soil salinity was insignificant in both soil layers $(p>0.05)$.

An increase trend of soil $\mathrm{Cu}, \mathrm{Pb}$ and $\mathrm{Zn}$ contents under different irrigation history was observed. Accumulation of $\mathrm{Cu}$ in both soil layers and $\mathrm{Zn}$ in the $10-20 \mathrm{~cm}$ soil layer was significant with RW irrigation years. While the differences in plots with different irrigation years were large, one could not simply attribute to such differences to the length of reclaimed water irrigation. The four parks with 9 year reclaimed water irrigation located between the 2th and the 3rd ring road, while the other three parks located between the 4 th and the 5 th ring road. With the longer anthropogenic activities such as traffic, construction and industry activities, more heavy metals were expected to accumulate in the 9 year irrigation parks with time through atmospheric deposition (Wu et al., 2010; Wang et al., 2012; Yuan et al., 2014). From a mass balance view, 3 or 6 years irrigation of reclaimed water could not result in significant changes of soil heavy metal contents showed by Table 3. Fig. 3 illustrated that the difference of soil heavy metal contents between treated plots and control plots was small and insignificant. Thus, the observed difference of soil $\mathrm{Cu}, \mathrm{Pb}$ and $\mathrm{Zn}$ contents among different irrigation history parks should be attributed to the variations of atmospheric deposition within the city and soil background.

Soil MBC in the $0-10 \mathrm{~cm}$ and $10-20 \mathrm{~cm}$ layers increased by $37.3 \%$ and $45.6 \%$, respectively, from 3 years to 9 years irrigation. For urease activity and invertase activity, the increase was $36.2 \%$ and $30.2 \%$, respectively, in the $0-10 \mathrm{~cm}$ soil layer, and $60.0 \%$ and $77.0 \%$, respectively, in the $10-20 \mathrm{~cm}$ soil layer. For the other three soil enzymes, their activities under different RW irrigation years maintained at a similar level. While changes of soil MBC, urease activity and invertase activity with irrigation years were insignificant by Tukey's tests, the result indicates that soil biological activities improved as the years of RW irrigation increased.

In summary, soil health conditions were improved as the years of RW irrigation increased, as shown by the significant increase in TN and SOM, and great increase of MBC, urease activity and invertase activity. The negative effects of RW irrigation due to accumulation of soil salinity and some heavy metals were generally insignificant. 


\section{Conclusions}

A comprehensive field investigation was conducted in 7 parks in Beijing, China to evaluate the effects of reclaimed water irrigation on health conditions of the urban green areas soils. Our main findings are:

(1) Reclaimed water irrigation improved the soil nutrient conditions. Soil total nitrogen, available phosphorus and organic matter content increased by $6-17 \%$ under reclaimed water irrigation. No significant change of soil $\mathrm{pH}$ was observed.

(2) Accumulation of salinity was observed under reclaimed water irrigation. The average $\mathrm{EC}_{\mathrm{e}}$ increased by about $20 \%$ in the two surface layers under RW irrigation. The average SAR increased significantly by $40 \%$ in the $0-10 \mathrm{~cm}$ layer and by $70 \%$ in the $10-20 \mathrm{~cm}$ layer. Changes of total boron content and total porosity were limited. There was no soil salinization but a slight soil alkalization under reclaimed water irrigation. Based on the data, significant permeability issue is not expected to occur.

(3) Accumulation of heavy metals in soils was negligible. Three of the six heavy metals were found to accumulate in soils, but the increase of their contents was less than $10 \%$ and was insignificant.

(4) Reclaimed water irrigation could significantly improve the soil microorganism activities, and then the soil health conditions. The average soil MBC was significantly increased by about $60 \%$ in the two surface soil layers. Except for urease, activities of the other four selected soil enzymes increased significantly from $7.7 \%$ to $109 \%$.

(5) Impacts of reclaimed water irrigation on soil properties depended on the length of irrigation. Both soil nutrient conditions (TN and SOM) and soil biological activities (soil MBC, urease activity and invertase activity) were improved with the increase of irrigation years, indicating that the soils become healthier with longer reclaimed water irrigation. No obviously negative impact was observed with the increase in years of reclaimed water irrigation, but attention should be paid to the higher SAR under longer reclaimed water irrigation.

\section{Acknowledgement}

We would like to acknowledge the financial support to this research from National Natural Science Foundation of China (\#41271501).

\section{References}

Adrover, M., Farrus, E., Moya, G., Vadell, J., 2012. Chemical properties and biologica activity in soils of Mallorca following twenty years of treated wastewater irrigation. J. Environ. Manage. 95, S188-192.

Anderson, J., 2003. The environmental benefits of water recycling and reuse. Water Sci. Technol. 3, 1-10.

Bao, S.D., 2000. The Soil Agrochemical Analysis, third ed. China agriculture press, Beijing (in Chinese).

Biggs, T.W., Jiang, B., 2009. Soil salinity and exchangeable cations in a wastewater irrigated area, India. J. Environ. Qual. 38, 887-896.

Candela, L., Fabregat, S., Josa, A., Suriol, J., Vigues, N., Mas, J., 2007. Assessment of soil and groundwater impacts by treated urban wastewater reuse. A case study: application in a golf course (Girona, Spain). Sci. Total Environ. 374, 26-35.

Chang, D.H., Ma, Z., 2012. Wastewater reclamation and reuse in Beijing: influence factors and policy implications. Desalination 297, 72-78.

Chen, W.P., Lu, S.D., Pan, N., Jiao, W.T., 2013. Impacts of long-term reclaimed water irrigation on soil salinity accumulation in urban green land in Beijing. Water Resour. Res. 49, 7401-7410.

Chen, W., Wu, L., Frankenberger, W.T., Chang Jr., A.C., 2008. Soil enzyme activities of long-term reclaimed wastewater-irrigated soils. J. Environ. Qual. 37, S36-42.

Chen, W.P., Zhang, W.L., Pan, N., Jiao, W.T., 2012. Ecological risks of reclaimed wate irrigation: a review. Environ. Sci. 33, 4070-4080 (in Chinese). de Miguel, A., Martínez-Hernández, V., Leal, M., González-Naranjo, V., de Bustamante, I. Lillo, J. Martín, I. Salas, JJ., Palacios-Díaz, M.P. 2013, Shortterm effects of reclaimed water irrigation: Jatropha curcas L. cultivation. Ecol. Eng. 50, 44-51.

Duncan, R.R., Carrow, R.N., Huck, M.T., 2009. Turfgrass and Landscape Irrigation Water Quality: Assessment and Management. CRC Press, Boca Raton, FL.

Frankenberger, W.T., Johanson, J.B., 1983. Method of measuring invertase activity in soils. Plant Soil 74, 301-311.

Gosewinkel, U., Broadbent, F.E., 1984. Conductimetric determination of soil urease activity. Commun. Soil Sci. Plant 15, 1377-1389.

Insam, H., Domsch, K.H., 1988. Relationship between soil organic-carbon and microbial biomass on chronosequences of reclamation sites. Microb. Ecol. 15, 177-188.

Jiao, Z.H., Huang, Z.B., Li, Y., Wang, W.P., Yan, B.L., Peng, L.C., Li, H.F., 2010. The effect of reclaimed water irrigation on soil performance and the microorganism. J. Agro-Environ. Sci. 29, 319-323 (in Chinese).

Johnson, J.L., Temple, K.L., 1964. Some variables affecting the measurement of catalase activity in soil. Soil Sci. Soc. Am. Proc. 28, 207-209.

Kang, M.S., Kim, S.M., Park, S.W., Lee, J.J., Yoo, K.H., 2007. Assessment of reclaimed wastewater irrigation impacts on water quality, soil, and rice cultivation in paddy fields. J. Environ. Sci. Health A 42, 439-445.

Kramer, M., Yerdei, G., 1960. Application of the method of phosphatase activity determination in agricultural chemistry. Sov. Soil Sci. 9, 1100-1103.

Li, D.S., Yang, J.S., Zhou, J., 1996. Measure and conversion of electrical conductivity of the salt affected soil extracts in the Huanghuaihai Plain. Chin. J. Soil Sci. 27, 285-287 (in Chinese).

Luo, L., Ma, Y., Zhang, S., Wei, D., Zhu, Y.G., 2009. An inventory of trace element inputs to agricultural soils in China. J. Environ. Manage. 90, 2524-2530.

Mancino, C.F., Pepper, I.L., 1992. Irrigation of turfgrass with secondary sewage effluent: soil quality. Agron. J. 84, 650-654.

Martinez, C.J., Clark, M.W., Toor, G.S., Hochmuth, G.J., Parsons, L.R., 2011. Accounting for the Nutrients in Reclaimed Water for Landscape. AE479. University of Florida Institute of Food and Agricultural Sciences, Gainesville. <http:// edis.ifas.ufl.edu/ae479>.

Nannipieri, P., Grego, S., Ceccanti, B., 1990. Ecological significance of the biological activity in soil. In: Stotzky, G., Bollag, J.M. (Eds.), Soil Biochemistry. Marcel Dekker, New York, pp. 293-355.

Palacios-Díaz, M.P., Mendoza-Grimon, V., Fernandez-Vera, J.R., RodriguezRodriguez, F., Tejedor-Junco, M.T., Hernandez-Moreno, J.M., 2009. Subsurface drip irrigation and reclaimed water quality effects on phosphorus and salinity distribution and forage production. Agric. Water Manage. 96, 1659-1666.

Qian, Y.L., Mecham, B., 2005. Long-term effects of recycled wastewater irrigation on soil chemical properties on golf course fairways. Agron. J. 97, 717-721.

Smith, C.J., Hopmans, P., Cook, F.J., 1996. Accumulation of Cr, Pb, Cu, Ni, Zn and Cd in soil following irrigation with treated urban effluent in Australia. Environ. Pollut. 94, 317-323.

Stevens, D.P., McLaughlin, M.J., Smart, M.K., 2003. Effect of long-term with reclaimed water on soils of Northern Adelaide Plains, South Australia. Aust. J. Soil Res. 41, 933-948.

Stevenson, I.L., 1959. Dehydrogenase activity in soils. Can. J. Microbiol. 5, 229-235.

Stewart, H.T., Hopmans, P., Flinn, D.W., Hillman, T.J., 1990. Nutrient accumulation in trees and soil following irrigation with municipal effluent in Australia. Environ. Pollut. 63, 155-177.

Toze, S., 2006. Reuse of effluent water - benefits and risks. Agric. Water Manage. 80, $147-159$.

Truu, M., Truu, J., Heinsoo, K., 2009. Changes in soil microbial community under willow coppice: the effect of irrigation with secondary-treated municipal wastewater. Ecol. Eng. 35, 1011-1020.

US Salinity Laboratory Staff, 1954. United States Department of Agriculture Handbook 60: Diagnosis and improvement of saline and alkali soils. U.S Salinity Laboratory Staff, California, p. 9.

Vance, E.D., Brookes, P.C., Jenkinson, D.S., 1987. An extraction method for measuring soil microbial biomass-C. Soil Biol. Biochem. 19, 703-707.

Wang, M.E., Bai, Y.Y., Chen, W.P., Markert, B., Peng, C., Ouyang, Z.Y., 2012. A GIS technology based potential eco-risk assessment of metals in urban soils in Beijing, China. Environ. Pollut. 161, 235-242.

Wang, R.H., Zhong, F.X., Ma, L.Y., 2011. Evapotranspiration characteristics of two lawn species for landscaping in Beijing. Scientia Silvae Sinicae 47, 194-198 (in Chinese).

Wang, Y.C., Zhang, J., Hao, B.G., 2007. Effects of irrigation with reclaimed water on the landscape plants mineral elements and soil. Chin. Landscape Archit., 62-65 (in Chinese).

Wei, F.S., Chen, J.S., Wu, Y.Y., Zheng, C.J., 1991. Study on the background contents on 61 elements of soils in China. Environ. Sci. 12, 12-19 (in Chinese).

Wu, S., Xia, X.H., Lin, C.Y., Chen, X., Zhou, C.H., 2010. Levels of arsenic and heavy metals in the rural soils of Beijing and their changes over the last two decades (1985-2008). J. Hazard. Mater. 179, 860-868.

Xu, J., Wu, L., Chang, A.C., Zhang, Y., 2010. Impact of long-term reclaimed wastewater irrigation on agricultural soils: a preliminary assessment. J. Hazard. Mater. 183, 780-786.

Yang, J., Chen, T.B., Lei, M., Liu, Y.L., Wu, W.Y., Zhou, J., 2011. Assessing the effect of irrigation with reclaimed water: the soil and crop pollution risk of heavy metals. J. Nat. Resour. 26, 209-217 (in Chinese).

Yuan, G.L., Sun, T.H., Han, P., Li, J., Lang, X.X., 2014. Source identification and ecological risk assessment of heavy metals in topsoil using environmental geochemical mapping: typical urban renewal area in Beijing, China. J. Geochem. Explor. 136, 40-47. 